\title{
Aplikasi Coat dan Film Pati Batang Aren untuk Mencegah Susut Berat dan Pencoklatan pada Buah Apel Terolah Minimal
}

\section{Application of Aren Stalk Starch Coat and Film to Prevent Weight Loss and Browning on Minimally Processed Apples}

\section{F. Sinung Pranata}

Fakultas Biologi Universitas Atma Jaya Yogyakarta, Jl. Babarsari No. 44, Yogyakarta 55281

E-mail: sinung@mail.uajy.ac.id

\begin{abstract}
Minimally processed fruits provide convenience and freshness characters. Weight loss is a critical factor affecting the shelf life of minimally processed apples. These apples were limited by brown coloration that develops on surface. The objective of this study is to evaluate the effectiveness of edible coat and film made from aren starch against weight loss and browning on minimally processed apples. Edible coat and film solutions were prepared from $3 \%(w / v)$ aren starch, 6\% (w/w) palmitic acid, and 1\% (w/v) sorbitol. Minimally processed apples were either dipped in the coating solution or wrapping by edible film and then stored at ambient temperature for 8 hours. Browning appearance was determined every 4 hours and weight loss of apples was measured every hour. Edible film was much effective on weight loss control than coating during storage. Color analysis showed that pati aren edible coating and film wrapping did not significantly delayed browning reaction on minimally processed apples.
\end{abstract}

Key words : pati aren, edible coat, edible film, weight loss, minimally processed apples

Diterima: 3 April 2003, disetujui 19 Agustus 2003

\section{Pendahuluan}

Buah terolah minimal adalah produk yang siap santap dengan tetap mempertahankan kesegaran buah aslinya. Tahap utama pengolahan buah terolah minimal meliputi pengupasan, penghilangan bagian tertentu, dan pemotongan. Lamikanra dan Watson (2001) melaporkan pemotongan buah dapat menimbulkan kerusakan pada permukaan sel dan injury stress pada buah. Kerusakan buah terolah minimal dapat pula disebabkan oleh perubahan warna, tekstur, cita rasa atau oleh mikrobia.

Susut berat merupakan faktor kritis yang mempengaruhi kualitas dan umur simpan buah terolah minimal. Hal ini berhubungan dengan kesegaran produk yang menjadi daya tarik produk terolah minimal. Reaksi enzimatis menimbulkan perubahan kenampakan buah terolah minimal yang lebih dikenal dengan pencoklatan. Enzim seluler yang bebas akan bereaksi dengan substrat menghasilkan komponen berwarna coklat. Pencoklatan pada beberapa produk pangan, seperti apel telah menjadi permasalahan utama di bidang pengolahan pangan.

Beberapa teknik yang digunakan untuk mempertahankan kualitas buah apel terolah minimal adalah dengan pemberian reagensia anti-pencoklatan asam askorbat. Asam askorbat merupakan inhibitor efektif enzim polifenol oksidase penyebab pencoklatan dengan jalan mereduksi komponen quinon (Sapers, 1993). Lebih lanjut Loaiza-Velarde dan Saltveit (2001) melaporkan blanching pada suhu $50^{\circ} \mathrm{C}$ selama 90 detik, mampu mengurangi pencoklatan pada daun selada.

Tien et al. (2001) melaporkan coating dengan kalsium kaseinat atau protein whey 
efektif menghambat pencoklatan pada apel dan kentang potong. Edible coat dan film dari gluten, protein kedelai, karagenan, dan chitosan dilaporkan juga efektif menurunkan kehilangan air pada produk precooked beef patties. Namun demikian penggunaan coating ternyata lebih efektif dibandingkan film wrapping.

Dalam penelitian ini akan dievaluasi perlakuan edible coating dan edible film wrapping untuk menghambat susut berat dan pencoklatan pada buah apel terolah minimal. Edible coat dan film dibuat dari pati batang aren yang telah diuji karakteristik sifatsifatnya.

\section{Metode Penelitian}

Bahan

Pati batang aren (Arenga pinnata Merr.) diperoleh dari daerah Purwosari Kabupaten Purworejo. Buah apel manalagi (Malus sylvetris Mill.) diperoleh dari pasar lokal dengan bentuk, ukuran, dan warna yang seragam. Sorbitol dan asam palmitat dari E’Merck Jerman.

Pembentukan larutan edible coat dan film

Larutan edible coat dan film dibuat dari $3 \%(\mathrm{~b} / \mathrm{v})$ pati batang aren dan $6 \%(\mathrm{~b} / \mathrm{b})$ asam palmitat mengikuti hasil penelitian terdahulu (Pranata dkk, 2002). Pembuatan edible coat dan film dimulai dengan melarutkan pati dalam aquades sebanyak $80 \mathrm{ml}$. Campuran diaduk dengan hot plate magnetic stirrer dan dipanaskan sampai suhu $70^{\circ} \mathrm{C}$ selama 15 menit. Selanjutnya larutan ditambah plasticizer sorbitol sebanyak $1 \% \quad(\mathrm{~b} / \mathrm{v}$ pati). Larutan dipanaskan kembali pada suhu $85^{\circ} \mathrm{C}$ sambil diaduk selama 15 menit. Pada tahap ini ditambah akuades sampai volume total $100 \mathrm{ml}$. Larutan edible coat akan digunakan secara langsung sebagai larutan coating pada tahap aplikasi, sedangkan pada pembuatan edible film setelah 10 menit larutan dituang ke dalam cetakan plastik ukuran $24 \times 16 \times 2 \mathrm{~cm}$ dan diratakan. Kemudian larutan dikeringkan dalam oven dengan suhu $50^{\circ} \mathrm{C}$ selama 24 jam. Film kemudian dilepas dari plat plastik dan disimpan dalam wadah yang berisi silika gel selama 12 jam. Selama 24 jam sebelum dilakukan pengukuran, film dikondisikan terlebih dahulu dalam wadah lain berisi silika gel selama 24 jam.

Aplikasi Coating dan film wrapping pada apel terolah minimal

Tahap ini merupakan wrapping dengan edible film pada buah apel terolah minimal yang dikemas. Terlebih dahulu buah apel dikupas bersih, kemudian dipotong-potong ukuran 2 x 2 x $1 \mathrm{~cm}$. Selanjutnya dilakukan pencelupan buah dengan beberapa variasi perlakuan, meliputi blanching dengan air pada suhu $50^{\circ} \mathrm{C}$ selama 90 detik, pencelupan dalam asam askorbat 5\%, blanching dengan asam askorbat 5\%. Setelah itu apel dimasukkan ke dalam cawan, masing-masing cawan berisi dua potong apel. Kemudian pada permukaan cawan ditutup dengan film. Film dilekatkan pada cawan dengan menggunakan selotip. Selanjutnya cawan yang berisi buah dan telah ditutup film ditimbang dan disimpan selama 8 jam.

Pada saat yang bersamaan disiapkan pula apel potong yang dicelup dalam larutan edible coat, kemudian dimasukkan ke dalam cawan, dan diangin-anginkan. Selanjutnya cawan yang berisi buah tersebut ditimbang dan disimpan selama 8 jam.

Penentuan susut berat buah apel terolah minimal

Buah apel terolah minimal yang telah dikemas selanjutnya diukur susut beratnya dengan cara ditimbang. Penimbangan dilakukan berturut-turut pada jam ke-0, 1, 2, 3, 4, 5, 6, dan 7. Persentase susut berat diukur berdasarkan pembagian antara berat buah pada jam ke-n dengan berat buah pada jam ke (n-7). 
Analisis warna buah apel terolah minimal

Pengukuran warna dilakukan pada dua posisi acak buah pada jam ke-0, 4, dan 8 . Analisis warna dievaluasi menggunakan kromameter dengan sistem warna L-a-b. Nilai lightness $(\mathrm{L})=100$ menunjukkan bahwa warna sampel adalah putih, sebaliknya nilai $\mathrm{L}=0$ menunjukkan hitam. Nilai sudut warna yang terbentuk diperoleh dari tangen b/a. Aksis a (warna merah) menunjukkan sudut warna $0^{\circ}$.

\section{Hasil dan Pembahasan}

Pada uji terdahulu diperoleh edible film yang memenuhi syarat yaitu nilai WVTR (water vapor transmission rate) paling kecil pada konsentrasi pati 3\% (b/v) dan asam palmitat $6 \%$ (b/b polimer), tebal film $0,11 \mathrm{~mm}$. (Pranata dkk, 2002). Pemilihan formulasi film ini berdasarkan pada fungsi utama edible film yaitu untuk menahan susut berat buah yang disimpan dengan cara menahan laju transmisi uap airnya. Pada tahap aplikasi ini dilakukan dua cara pembuatan bahan edible, yaitu pencelupan (coating) dan pembungkusan (wrapping). Kedua perlakuan tersebut dikombinasikan dengan perlakuan pendahuluan pada buah apel terolah minimal, yaitu perlakuan blanching dan celup.

Kemampuan edible coating dan film wrapping dengan pati batang aren untuk memperkecil susut berat apel terolah minimal dapat dilihat pada Gambar 1. Hasil menunjukkan bahwa penutupan wadah dengan film pati batang aren mampu memperkecil susut buah apel selama penyimpanan secara signifikan dibandingkan kontrol dan perlakuan coating. Hal ini disebabkan pada perlakuan coating memerlukan tahap pengeringan yang dapat menyebabkan kehilangan cairan buah. Kehilangan cairan buah yang cukup tinggi merupakan salah satu kerugian perlakuan coating (McHugh dan Senesi, 2000). Fenomena ini tidak dijumpai pada perlakuan wrapping.

Keuntungan perlakuan wrapping untuk memperkecil susut berat apel ternyata diikuti dengan kemampuan untuk memperkecil perubahan warna buah akibat browning. Pada
Gambar 2 terlihat bahwa perlakuan wrapping sampai 8 jam menghasilkan warna apel yang masih sama dengan kontrol. Penggunaan metode wrapping lebih efektif untuk menghambat pencoklatan dibandingkan metode coating. Hal ini dipengaruhi oleh ketebalan film yang digunakan untuk wrapping, sehingga dapat menghambat penetrasi gas oksigen. Wrapping juga berfungsi sebagai penahan hilangnya komponen tertentu pada apel yang disimpan.

Sama halnya dengan perlakuan wrapping sebelumnya, kombinasi perlakuan blanching dengan wrapping juga berpengaruh secara signifikan terhadap susut berat apel selama penyimpanan (Gambar 3). Kombinasi perlakuan coating dengan blanching dengan air tidak berbeda nyata dengan kontrol. Hal ini menunjukkan bahwa perlakuan coating yang dikombinasi dengan blanching dengan air tidak mampu mencegah susut berat apel selama penyimpanan.

Kombinasi perlakuan wrapping atau coating dengan blanching dengan air setelah 4 jam penyimpanan ternyata tidak mampu menghambat perubahan warna apel akibat pencoklatan (Gambar 4). Hal ini kemungkinan disebabkan oleh pengaruh media blanching yang digunakan yaitu air. Dalam media air kemungkinan gas oksigen terlarut cukup tinggi, sehingga reaksi browning kemungkinan juga cukup cepat terjadi. Aktivitas polifenol oksidase dipengaruhi oleh adanya substrat polifenol, ketersediaan oksigen, dan konsentrasi enzim (Tien et al., 2001). Kontak apel dengan air pada saat proses blanching selama 90 detik kemungkinan mengakibatkan penetrasi oksigen lebih cepat, sehingga dapat dinyatakan proses blanching tersebut lebih berpengaruh terhadap pencoklatan dibandingkan dengan perlakuan wrapping atau coating.

Pada Gambar 5, terlihat bahwa perlakuan wrapping yang dikombinasi dengan perlakuan blanching asam askorbat mampu memperkecil laju susut berat apel. Perlakuan coating tidak mampu memperkecil susut berat apel seperti halnya pada kontrol. Hal ini menjelaskan bahwa perlakuan pengeringan selama coating kemungkinan berpengaruh terhadap kehilangan cairan buah. Selain itu perlakuan coating membutuhkan persyaratan 
lain, misalnya dalam hal mudah tidaknya larutan coating melekat pada bahan. Fenomena ini akan sangat dipengaruhi oleh sifat bahan yang akan di-coating. Hasil serupa juga dilaporkan oleh McHugh dan Senesi (2000) bahwa penambahan asam askorbat dan asam sitrat ke dalam larutan coating apple puree tidak berpengaruh signifikan terhadap susut berat apel.

Penggunaan blanching dengan asam askorbat telah diketahui mampu menghambat aktivitas enzim polifenol oksidase. Asam askorbat akan mereduksi quinon kembali ke bentuk fenol sebelum dapat menimbulkan warna coklat pada buah (Sapers, 1993). Hal ini terbukti dari kemampuan blanching asam askorbat dan wrapping seperti terlihat pada Gambar 5. Perlakuan blanching dengan asam askorbat yang dilanjutkan dengan wrapping merupakan perlindungan ganda terhadap reaksi pencoklatan. Sementara hasil penelitian Loaiza-Verlarde dan Saltveit (2001) menunjukkan bahwa blanching dalam air pada suhu $50^{\circ} \mathrm{C}$ selama 90 detik mampu menginaktifkan polifenol oksidase pada daun selada.

Kombinasi perlakuan wrapping dengan pencelupan asam askorbat berpengaruh signifikan terhadap laju susut berat apel (Gambar 6). Namun perlakuan coating tidak mampu memperkecil susut berat apel selama penyimpanan. Hasil serupa ditemukan pula pada perlakuan kontrol. Fenomena ini menjelaskan beberapa keuntungan dari perlakuan wrapping, yaitu film yang lebih tebal akan menunjang sifatnya sebagai penahan (barrier) dan pada wrapping tidak memerlukan tahap pengeringan seperti pada coating, sehingga kerusakan yang berkaitan dengan pengambilan air produk pada saat coating dapat diminimalkan.

Laju perubahan warna apel pada kombinasi perlakuan wrapping dengan pencelupan asam askorbat lebih rendah dibandingkan dengan perlakuan coating (Gambar 7). Hal ini ditunjukkan dengan perubahan warna apel yang sama setelah disimpan selama 8 jam antara perlakuan wrapping, sehingga dapat dinyatakan bahwa kombinasi perlakuan wrapping dengan pencelupan asam askorbat lebih efektif untuk mencegah pencoklatan pada apel dibandingkan coating dan kontrol. Hasil penelitian ini ditunjang dengan penelitian Lamikanra dan Waston (2001) bahwa pencelupan buah melon potong pada asam askorbat selama 1 menit mampu menurunkan aktivitas enzim polifenol oksidase dan peroksidase selama penyimpanan.

\section{Kesimpulan}

Berdasarkan hasil penelitian tersebut, maka dapat disimpulkan bahwa perlakuan wrapping lebih efektif untuk menahan susut berat apel terolah minimal dibandingkan coating. Baik perlakuan wrapping maupun coating belum mampu menunjukkan hasil yang signifikan untuk menahan pencoklatan pada apel terolah minimal.

\section{Ucapan terima kasih}

Penulis mengucapkan banyak terima kasih kepada Dr.Ir.Djagal Wiseso Marseno, M.Agr dan Prof. Dr. Haryadi, M.App.Sc. yang telah membimbing penulis, sehingga penelitian ini dapat berlangsung dengan baik.

\section{Daftar Pustaka}

Lamikanra, O. and M. A. Watson. 2001. Effects of Ascorbic Acid on Peroxidase and Polyphenol Oxidase Activities in Fresh-Cut Cantaloupe Melon. J. Food Sci. 66 (9): 1283-1286.

Loaiza-Velarde, J. G. and M. E. Saltveit. 2001. Heat Shocks Applied either before or after Wounding Reduce Browning of Lettuce Leaf Tissue. $J$. Amer. Soc. Hort. Sci. 126 (2): 227-234.

McHugh, T. H. and E. Senesi. 2000. Apples Wraps: a Novel Method to Improve the Quality and Extend the Shelf Life of Fresh-Cut Apples. J. Food Sci. 65 (3): 480-485. 
Pranata, S., D. W. Marseno, and Haryadi. 2002. Karakteristik Sifat-sifat Fisik dan Mekanik Edible Film Pati Batang Aren (Arenga pinnata Merr.). Biota. 7 (3): 121-130.

Sapers, G. M. 1993. Browning of Foods: Control by Sulfites, Antioxidants, and other Means. Food Tech. 75-84.

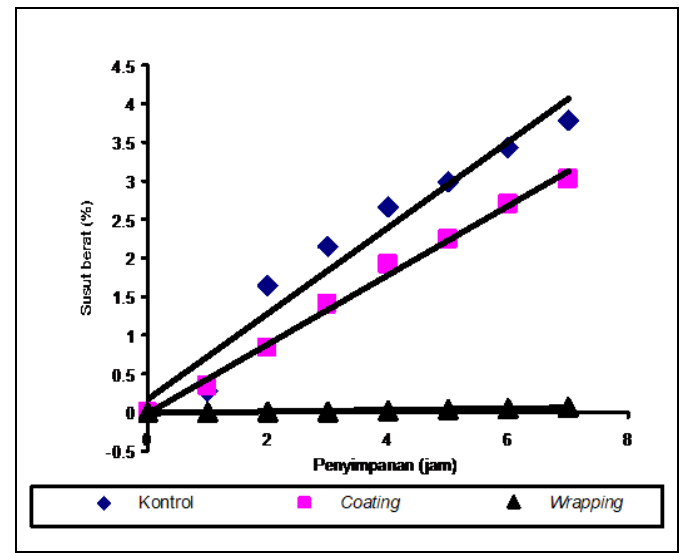

Gambar

1. Pengaruh wrapping dan coating terhadap susut berat apel terolah minimal

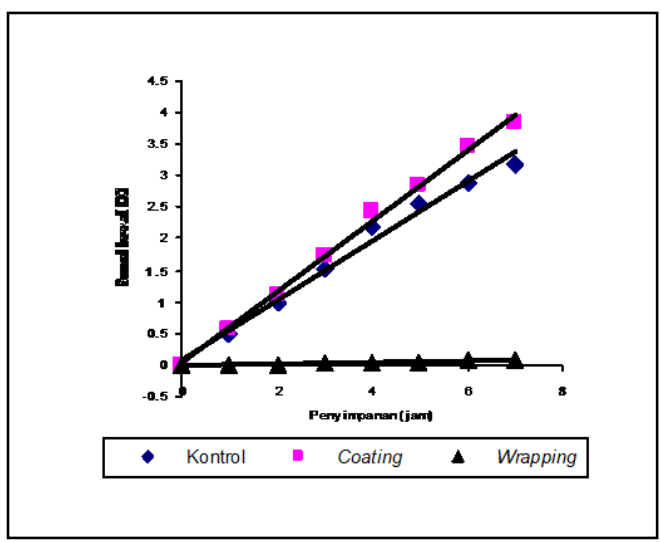

GGambar 3. Pengaruh kombinasi blanching air dengan wrapping atau coating terhadap susut berat apel terolah minimal
Tien, C. L., C. Vachon, M. A. Mateescu, and M. Lacroix. 2001. Milk Protein CoatingsPrevent Oxidative Browning of Apples and Potatoes. J. Food Sci. 66 (4): 512-516.

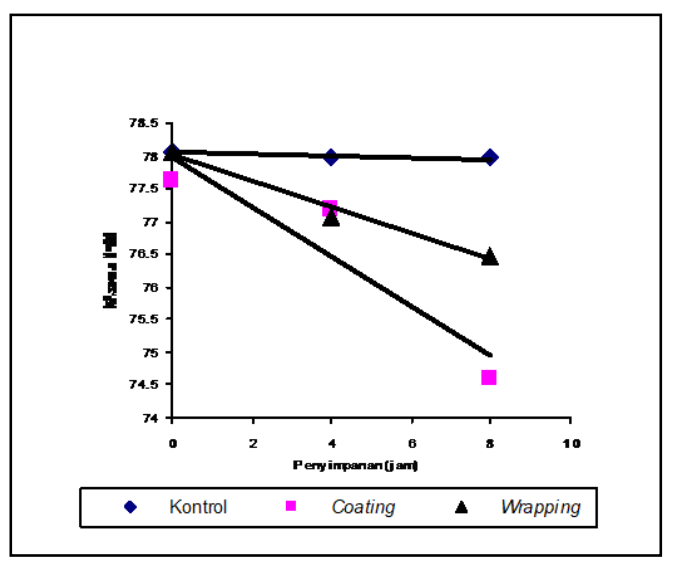

Gambar 2. Pengaruh wrapping dan coating terhadap penurunan warna apel terolah minimal

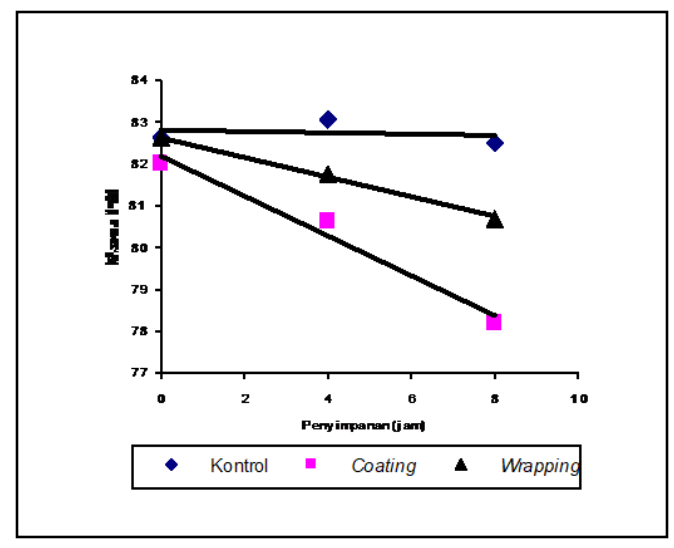

Gambar 4. Pengaruh kombinasi blanching air dengan wrapping terhadap penurunan warna apel terolah minimal 


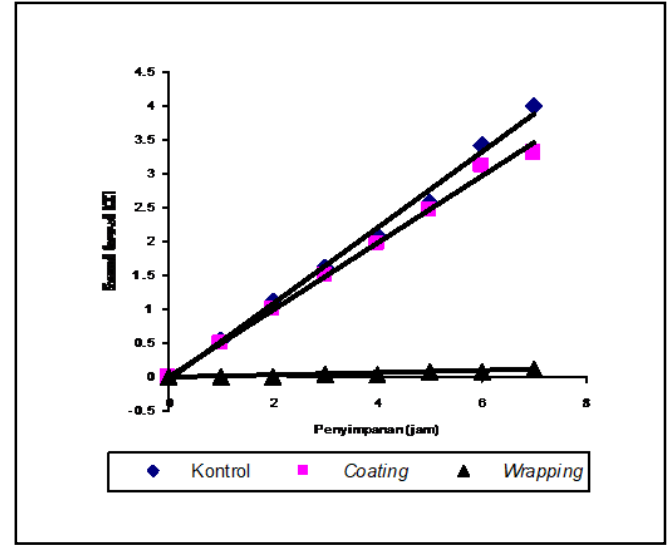

Gambar 5. Pengaruh kombinasi blanching asam askorbat dengan wrapping atau coating terhadap susut berat apel terolah minimal

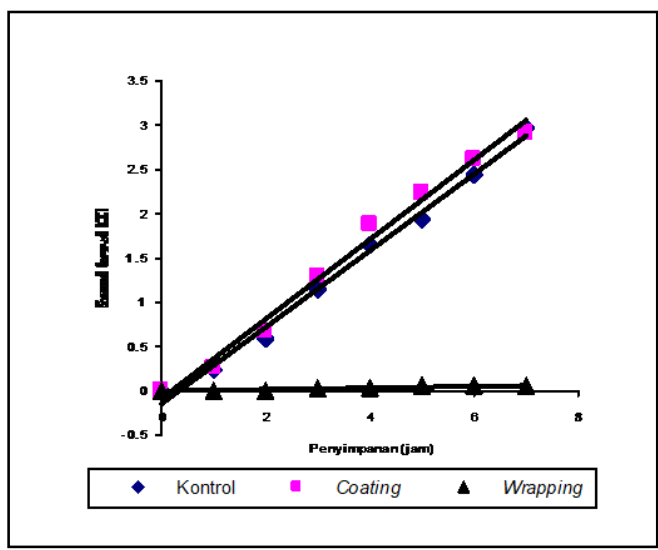

Gambar 7. Pengaruh kombinasi pencelupan asam askorbat dengan wrapping atau coating terhadap susut berat apel terolah minimal

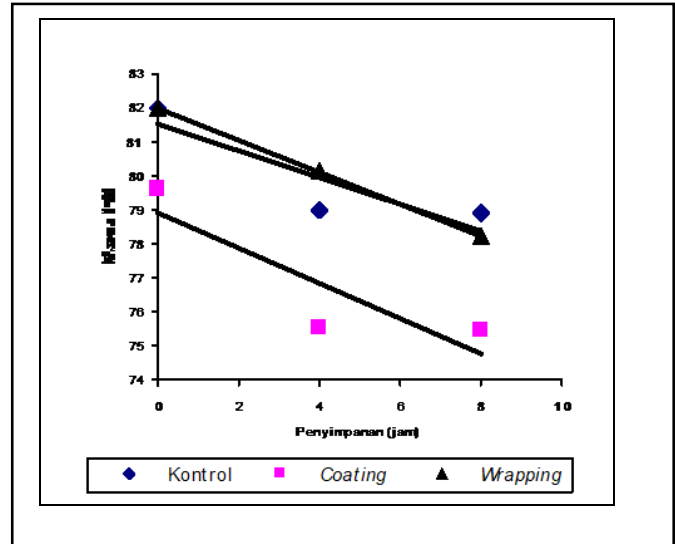

Gambar 6. Pengaruh kombinasi blanching asam askorbat dengan wrapping atau coating terhadap penurunan warna apel terolah minimal

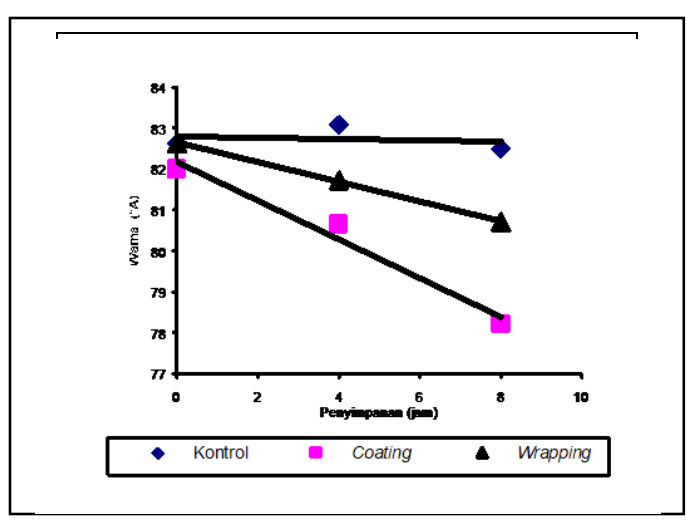

Gambar 8. Pengaruh kombinasi pencelupan asam askorbat dengan wrapping atau coating terhadap penurunan warna apel terolah minimal 